DOI $10.15290 /$ cnisk.2017.02.03.01

DR HAB. BEATA WALĘCIUK-DEJNEKA, PROF. UP-H

orcid.org/0000-0002-6034-5129

Uniwersytet Przyrodniczo-Humanistyczny w Siedlcach

\title{
Samodzielna, odważna, nowoczesna: historia Marii Morzyckiej-Obuchowskiej w świetle wybranych fragmentów jej Pamiętników ${ }^{1}$
}

\section{Streszczenie}

Artykuł jest próba literaturoznawczego spojrzenia na pamiętniki pisane przez kobietę. Ukazuja one wiele szczegółów z powstania 1863 r., zsyłki na Syberię czy zamordowanie cara Aleksandra II. Niezwykle sugestywnie i obrazowo zostały przedstawione wydarzenia $z$ buntów chłopskich na Ukrainie, współżycie dwóch wspólnot w Kamieńcu Podolskim czy stosunek Rosjan do Polaków na wschód od Charkowa. Ale przede

\footnotetext{
1 Niniejszy artykuł wpisuje się w autorski cykl projektu „kobiecego "bycia-w-świecie»". Inne powstałe artykuły to m.in.: B. Walęciuk-Dejneka, Nowa „ja”. Autorskie stwarzanie siebie na podstawie „Pamiętników” Zofii Tołstojowej (wybór) [w:] Tożsamość kobiet: silne indywidualności $w$ sztuce, literaturze i religii, red. J. Posłuszna, B. Walęciuk-Dejneka, Kraków 2014, s. 49-56; Eadem, Kobieca koncepcja „bycia-w-świecie”: „ja” w rodzinie. Z „Pamiętników” Zofii Tołstojowej, „Prace Literaturoznawcze" 2015, nr 3, s. 197-208; Eadem, Kobiece doświadczanie drogi: „ja” w podróży. Rozważania na podstawie „Wspomnien”" Anny Dostojewskiej, „Prace Literaturoznawcze” 2016, nr 4, s. 99-113; Eadem, W cieniu. Zofii Tołstojowej (1844-1919) i Anny Dostojewskiej (1846-1918) skrywane pisarstwo, „Studia $z$ Historii Społeczno-Gospodarczej" [online], 2016, t. 16, s. 111-121 [Dostęp: 20.09.2017]. Dostępny w World Wide Web: <http://bit.ly/2AWysmL>. Heideggerowska koncepcja „bycia-w-świecie”, głęboko zakorzeniona w refleksji humanistycznej, traktowana jest tu jako metaforyczna, nie zaś jako koncepcja badawcza, oparta na fundamentalnej teorii filozofa, konstytuujaca nierozerwalna jedność bycia i świata w różnorodnych aspektach.
} 
wszystkim ukazują niesamowita kobietę, która z niesamodzielnej, wrażliwej dziewczynki przeobraziła się w dojrzała matkę, odpowiedzialna, samodzielna, odważna, bohaterkę swoich czasów, bioraca własny los i los innych w swoje ręce. Ponadto kobietę o szerokich horyzontach myślowych, z pewną nowoczesnością poglądów, prekursorkę równości społecznej, bystra obserwatorkę i świadka wydarzeń politycznych, zmian dziejowych, na które potrafi spojrzeć krytycznie, również patriotkę. Niewiastę zaangażowaną, czynną w życiu publicznym, działaczkę.

Słowa kluczowe: Maria Morzycka-Obuchowska, pamiętniki, kobieta, feministka, literatura polska, XIX/XX w.

\title{
INDEPENDENT, BRAVE, MODERN: THE STORY OF MARIA MORZYCKA-OBUCHOWSKA IN THE LIGHT OF SELECTED FRAGMENTS OF HER "PAMIĘTNIKI"
}

\begin{abstract}
The following article is an insight into life revealed through diaries written by a woman. They make a valuable source of detailed information on such events as the Polish uprising of 1863, deportation to Siberia or the assassination of Tsar Alexander II. The diaries provide the reader with the first-hand and vivid accounts of peasant revolts in Ukraine, the coexistence of different nations in Kamieniec Podolski or the nature of Russian-Polish relations east of Charków. But above all, the diaries portray Maria Morzycka-Obuchowska as a remarkable woman, who changed from a dependent, and sensitive girl into a responsible, independent and brave mother, the heroine of her times. What emerges, it the image of a modern, broad-minded woman, a forerunner of social equality, a bright observer of political developments, and an avid patriot.
\end{abstract}

Keywords: Maria Morzycka-Obuchowska, diaries, woman, feminist, Polish literature, 19th and 20th century

Pamiętniki, podobnie jak wspomnienia, dzienniki, diariusze podróżnicze czy listy, należą do narracji osobistych, opowiadających nie tylko o ich autorze w konwencji historii, ujawniajac przy tym pewną indywidualną wizję świata i podmiot mówiący w tym 
świecie oraz jego życie, ale również niosacych informacje o epoce, o panujących światopoglądach, trendach, estetyce, krajach, miejscach i ludziach. Ilustruja przemiany kulturalne, kulturowe, społeczne, mentalne, wreszcie obyczajowe. Jednostka zaś świadomie próbuje określić w nich swoje miejsce, także swoją tożsamość.

Wypowiedzi autobiograficzne tworzone przez kobiety zaistniały w kulturze europejskiej kilka wieków temu, natomiast badanie pewnych ich rysów datuje się od kilku dziesięcioleci. Jak podkreślają badacze ${ }^{2}$, kobiecą autobiografistykę wyróżnia w tej grupie przede wszystkim oryginalne, nieszablonowe i indywidualne ujęcie oraz podejście w przekazywaniu treści. Życiowe doświadczenia i obserwacje transponowane w pismo (pamiętnik czy dziennik) wyłaniają nie zawsze oczywistą i dostrzegana, ale dynamiczna, kobieca perspektywę oglądu, autentyczną i podbudowaną emocjami. Chodzi w niej również o „samookreślenie” odnoszące się, jak wskazuje Brigitte Gautier, do kobiecej tożsamości, kobiecego życia i kobiecej narracji : a więc kobiecy podmiot piszacy, podmiot posiadający płeć, która ma wpływ na charakter tworzonego tekstu. Według Małgorzaty Czermińskiej pamiętnik, który jest najbardziej podobny do autobiografii, ma taką samą konstrukcję czasową. Różni się jedynie ukształtowaniem podmiotu, który w pamiętniku odgrywa mniejsza rolę, eksponuje raczej wydarzenia, w których brał udział, niż swoje przeżycia wewnętrzne ${ }^{4}$. Przedstawia dokonania jednostki, jej zamiary i doświadczenia, opowiada historię rodziny na tle historii świata.

2 Por. prace na temat autobiografii kobiet, m.in.: T. Czerska, Między autobiografia a opowieścia rodzinna. Kobiece narracje osobiste $w$ Polsce po 1944 roku w perspektywie historyczno-kulturowej, Szczecin 2011; A. Pekaniec, Nie tylko dzienniki. Oryginalne warianty kobiecej literatury dokumentu osobistego (na wybranych przykładach), „Ruch Literacki” 2012, nr 4/5, s. 451-463; Eadem, Czy $w$ tej autobiografii jest kobieta? Kobieca literatura dokumentu osobistego od poczatku XIX wieku do wybuchu II wojny światowej, Kraków 2013; A. Mrozik, Akuszerki transformacji. Kobiety, literatura i władza w Polsce po 1989 roku, Warszawa 2012.

3 B. Gautier, Zaklęcia czarodziejki Vivien, czyli o autobiografii kobiecej [w:] Krytyka feministyczna. Siostra teorii i historii literatury, red. G. Borkowska, L. Sikorska, Warszawa 2000, s. 152.

4 M. Czermińska, O autobiografii $i$ autobiograficzności [w:] Autobiografia, red. M. Czermińska, Gdańsk 2009, s. 14. 


\section{Historia rodziny - rodzina w historii ${ }^{5}$}

Taką perspektywę oglądu rzeczywistości przyjęła żyjąca w XIX w. Maria Morzycka-Obuchowska, autorka niezwykle cennego dokumentu autobiograficznego, który w wersji oryginalnej (jako manuskrypt) znajduje się w Muzeum Stefana Żeromskiego w Nałęczowie. Przedrukowany został w całości (aneks) w książce opowiadajacej o poszukiwaniu korzeni, tworzeniu genealogii i losach ziemiańskiej rodziny Pieńkowskich ${ }^{6}$. Trzeba tu też zaznaczyć, iż przy analizach i interpretacjach gatunków pamiętnikarskich czy dziennikarskich pojawiaja się kwestie dodatkowe, związane $z$ prawdziwością i szczerością przekazywanych faktów, zanotowanych zdarzeń, przywoływanych ludzi, miejsc, dat itp. Na ogól $\mathrm{w}$ wielu momentach nie jesteśmy $\mathrm{w}$ stanie stwierdzić autentyczności czy nieautentyczności zachowanych archiwaliów. Przyczyny owej deformacji prawdy moga być różnorodne. Jak wskazuje Władysław Czapliński, są to m.in.: zawodność pamięci, naturalna tendencja do koloryzowania i przejaskrawiania pewnych wydarzeń czy postaci lub pochopne uleganie własnym sympatiom i antypatiom ${ }^{7}$. $Z$ socjologiczno-psychologicznego punktu widzenia w prywatnych wspomnieniach interesujące sa zarówno spisane przez autorów fakty prawdziwe, jak też wszelkie kłamstwa i złudzenia dotyczace jego własnej osoby, ponieważ jest to „społeczne wyrażanie do urzeczywistniania tej dażności”. Poza tym dla badacza literatury, a może nie tylko, wiarygodność tekstów pamiętnikarskich w przypadku ich zgłębiania należy raczej do wytycznych drugorzędnych.

Maria Morzycka była daleka krewna autora publikacji o rodzinie Pieńkowskich. Jej zapiski, na co wskazuje Jerzy Klijanienko-Pieńkowski, sa bezcennym świadectwem życia Polaków $w$ za-

\footnotetext{
5 Nazwę zapożyczyłam od Tatiany Czerskiej - patrz Eadem, op. cit., s. 37.

6 J. Klijanienko-Pieńkowski, Pan Pieńkowski? Da, oni żili zdieś... Wołyń, Syberia, Nałęczów, losy ziemiaństwa na podstawie dokumentów rodzinnych, Stalowa Wola 2012.

7 W. Czapliński, Pamiętnikarstwo jako źródło dla historyka nowożytnego, „Pamiętnikarstwo Polskie" 1972, nr 2, s. 2-7, cyt. za: A. Cieński, Z dziejów pamiętników w Polsce, Opole 2002, s. 31.

8 Cyt. za A. Cieński, op. cit., s. 32-33.
} 
w swoich pamiętnikach: na rogu Mazowieckiej i Świętokrzyskiej $w$ kamienicy, która zdaje mi się, była własnościa doktora Malon ${ }^{11}$. Ojciec Marii był inżynierem dróg i komunikacji, edukację odbył w Petersburgu, w Korpusie Kadetów. Lubił muzykę i poezję, pisał wiersze. Matka zaś, z domu Lasocka, słynęła z piękności, dobroci (...), wychowywana przez babkę, pania Geport, staruszkę z czasów stanisławowskich, która piękność $i$ staranie koło jej utrzymania za główne widziała cnoty $w$ kobiecie ${ }^{12}$. Maria pochodziła $z$ dość zamożnej rodziny. Ceniono w niej wykształcenie, edukację, popierano czytelnictwo, dbano o rozwój duchowy i intelektualny dzieci, a o sprawy materialne zabiegano na tyle, na ile były one potrzebne do codziennego funkcjonowania rodziny i prowadzenia gospodarstwa. Od najmłodszych lat uczyła się gry na fortepianie: $z$ Warszawy ojciec sprowadził nowiutki fortepian, zaczęłam się uczyć grać (...), wygrywałam rozmaite polki, walce, mazury dla dzieci, a nawet dla starszych ${ }^{13}$, lubiła opowiadać bajki i czytać ambitne ksiażki, które wówczas jako dziecko uważała za „niepotrzebne i niezrozumiałe", a były to: Żyd wieczny tułacz, Konrad Wallenrod, Tajemnice Paryża. Około 1848 r. rodzina przeprowadziła się do Międzyrzeca. Na lekcje domowe przychodziła prywatna nauczycielka sprowadzona ze stolicy, która skończyła instytut $w$ Puławach $^{14}$. W sierpniu 1852 r. Maria trafiła na pensję do pani Kucharskiej do Warszawy, „właścicielki pensji 3-klasowej”, mieszczącej się na rogu Świętokrzyskiej i Mazowieckiej w kamienicy państwa Cieleckich. Wówczas była to jedna $z$ pierwszych pensji, a

pani przełożona uważana była za esprit fort, należała do kółka entuzjastek, spokrewniona była przez Duninów (...) ze Żmichowska (...). Wysoka, szczupła, bardzo silna brunetka o cerze śniadej, $z$ przebijajacym matowym rumieńcem, oczy miała błyszczące, bardzo czarne, przenikliwe, ostre, usta wąskie, zacięte ${ }^{15}$.

\footnotetext{
11 Pamiętniki Marii Morzyckiej-Obuchowskiej [w:] J. Klijanienko-Pieńkowski, op. cit., s. 87.

12 Ibidem.

13 Ibidem, s. 91.

14 Ibidem, s. 96.

15 Ibidem, s. 103.
} 
W 1857 r., mając 16 lat, wyszła za mąż za Juliana Morzyckiego, jak sama pisze: mój narzeczony miał pod czterdziestkę, a wesele było starodawne, staroświeckie, $z$ kapela, setka krewnych i przyjaciót, którzy nigdy ani iskry przyjacielskich uczuć do naszego domu nie żywili ${ }^{16}$. Morzyccy mieli kilkoro dzieci: Rozalię Marię Paulinę, Julię Marię Paulinę, Marię Paulinę Katarzynę, Paulinę, Faustynę, Wacławę i Jana. W 1863 r. za udział w powstaniu mąż został uznany za „politycznego przestępcę”, osądzony na 20 lat ciężkich robót i 2 września wysłany na Syberię. Maria towarzyszyła mu w drodze na katorgę, również w Usolu, gdzie zostali osadzeni, co ze szczegółami opisała w pamiętniku. W czasie powrotu $z$ Syberii do kraju powzięła decyzję, że opuści męża:

Wracali z moim mężem, a ja z Petersburga przyjechałam, ażeby się $z$ nimi widzieć. Na pierwszej stacji pożegnałam się z mężem i odetchnęłam swobodniej, moje postanowienie było rozłączyć się z nim na zawsze ${ }^{17}$.

Wspólne życie, 14 lat spędzonych razem, uważała za męczarnię,

równająca się śmierci, [zaś wstręt] (...) równał się prostytucji sankcjonowanej przez kościól, a co więcej przez obyczaje, od których odstapienie równało się pręgierzowi i zaliczenie do wyrzutków społeczeństwa. Zdecydowałam się na wszystko, aby tylko nie powtórzyło się to życie okropne ${ }^{18}$.

W Petersburgu, dokąd się udała, by wyjednać carskie ułaskawienie dla męża, poznała adwokata Marcina Wrońskiego. To dla niego porzuciła rodzinę (męża i dzieci), także $z$ nim miała syna i córkę. Jak sama zaznacza w pamiętnikach: wzięliśmy ślub, ażeby uprawnieniem zwiazku naszego dać dzieciom prawa, bo wtedy było prawo takie, że dopiero po zawarciu małżeństwa można było prosić o usynowienie dzieci ${ }^{19}$. Rozwodu jednak nie dostała. Swoje

\footnotetext{
${ }_{16}$ Ibidem, s. $115-116$

17 Ibidem, s. 227.

18 Ibidem.

19 Ibidem, s. 324.
} 
Pamiętniki napisała w 1905 r., nie zostały one jednak zakończone, urywają się w momencie wyjazdu Marii do Genewy, około 1898 lub 1899 r.

Jako protestantka ponoć została pochowana na cmentarzu w Lublinie ${ }^{20}$.

\section{Fragmenty codzienności: ,ja w małżeństwie”}

Pamiętniki Marii Morzyckiej-Obuchowskiej sa jej osobistymi relacjami, „sprawozdaniami” ze zdarzeń prywatnych, wydarzeń historycznych, opisami różnorodnych osób, miejsc, zachowań. Ale sa również wspaniałą, skrupulatną charakterystyka jej stanów duszy, myśli, rozterek, smutków i radości dnia codziennego. W pamiętniku jako gatunku podmiot eksponuje wydarzenia, w których brał udział, mniej natomiast przeżyć własnych, o czym już wspominaliśmy. Przekaz Marii Morzyckiej-Obuchowskiej nie do końca potwierdza to założenie. Jej przedstawienia, chociaż zawierają mnóstwo opisów, niezwykle przydatnych dla historyków, badaczy obyczajowości czy kultury XIX w., to i tak dużo bardziej skupione sa na życiu wewnętrznym, przedstawiaja stany psychiczne i duchowe, lęki i obawy, codzienne zmagania $z$ problemami, traumy i obsesje.

Małżeństwo Marii, 16-letniej dziewczyny, z dużo starszym Julianem Morzyckim nie należało do szczęśliwych i udanych. Nie była ona zachwycona ani mężem, ani związkiem, chociaż starała się wypełniać role przypisane w XIX-wiecznych realiach kobiecie, przede wszystkim spełniać powinności wynikajace $z$ faktu bycia żoną. Uczucia i doznania, jakie towarzyszyły jej tuż po ślubie, świadczą nie tylko o braku doświadczenia w relacji z mężczyzna, ale przede wszystkim o braku miłości do człowieka, za którego wyszła za mąż (wydano ją za mąż):

Ja jednak nie byłam zachwycona, ręka mojego męża szukała mojej, ramię jego otaczało moja kibić, a usta szukały ust moich, byłam

${ }^{20}$ Ibidem, s. 83. 
przestraszona, czemu, ach czemu, myślałam, ktoś nie pojechał ze mna, dlaczego zostawił mię samą $(\ldots)^{21}$.

Słowa rozżalonej, samotnej kobiety zawieraja mocne i dosadne niekiedy określenia i nazwania, wypowiedzi pod adresem męża stanowią uogólnienie wszelkich praw mężczyzn wobec kobiet, silniejszych wobec słabszych, niesprawiedliwych i stronniczych wobec bezbronnych i delikatnych. Świadczą o rodzącej się już wówczas w Marii niezależności, odwadze, samodzielności i pewnym wyzwoleniu, odstapieniu od schematów, w jakich w XIX w. postrzegano życie kobiety w rodzinie patriarchalnej: jako oddanej, wiernej mężowi, dobrej matki i pracowitej gospodyni domowej. Maria była inna:

Zostałam sama i zaczęło się życie mężatki, nauka młodej kozy obowiązków małżeńskich (...) Zaczęło się ciężkie życie niewolnicy, haremowej huryski $z$ niekochanym, starym mężczyzna, prostytucja w pełni; oznajmianie młodej istoty, która dopiero rozwijać się zaczyna, $z$ wyrafinowana rozpusta, rozpustą sankcjonowana prawem mężczyzny, zwyczajem, uzurpacja praw silniejszego. Słabe, nierozwinięte stworzenie w rękach mężczyzny, któremu służy za zabawkę, zadowalające jego zmysłowe żądze. Wstrętne to czasy, które dreszczem przejmują ${ }^{22}$.

Siedem długich, trudnych, ciężkich i znienawidzonych lat życia w Lachowcach Maria spędzała w samotności, na czytaniu i marzeniach: zostawałam sama, czasem na cały tydzień, samotność mie nie przerażała, błakałam sie po domu i czytałam, upijałam sie czytaniem, wszelkiego rodzaju powieściami i żyłam fantazją ${ }^{23}$. Była kobietą inteligentna, oczytana i zorientowana w literaturze i kulturze światowej: znała powieści Dumasa, Balzaka, interesowała się filozofią, książki stanowiły dla niej wyzwolenie, chwilową ucieczkę od przygnębiajacej monotonii i szarzyzny życiowej, powodowały radość. Wyczerpana psychicznie pisała: Smutne więzienie młodego stworzenia [mając na myśli dom - B.W.D] (...) przez te 6 lat mego

\footnotetext{
${ }^{21}$ Ibidem, s. 117.

22 Ibidem.

${ }^{23}$ Ibidem, s. 119.
} 
życia nie pamiętam jednej przyjemnej chwili, która by zostawiła jasne wspomnienie $w$ duszy ${ }^{24}$. Nawet uczucia macierzyńskie, miała już bowiem czworo dzieci, nie mogły zastapić żalu, rozczarowania i beznadziejności: gromadka czworga dzieci otaczała mie, ale to nie mogło zadowolić zupełnie nierozwiniętej jeszcze duszy (...) kochaŁam dzieci, o ile na to zdolna $w$ tym czasie być mogłam, $w$ czasie, którego $z$ nich pograżałam się $w$ rozpaczy ${ }^{25}$.

Rozmyślania nad samą sobą, nad swoim życiem, rozważania osobistych sytuacji, próby kreowania własnego „ja”, stwarzania siebie, konstruowania swojej tożsamości, to proces twórczy, który za Pawłem Rodakiem można nazwać „aktem autointerpretacji”26 to jeden $z$ głównych motywów przewijajacych się w pamiętnikach Marii. Za przykład, jeden $z$ wielu, niech posłuży podsumowanie związku małżeńskiego $z$ Julianem Morzyckim, kiedy bohaterka podjęła już decyzję o odejściu od niego. Rozgoryczona wyznawała:

Wziął moją młodość, lepiej powiedzieć dzieciństwo, a w zamian dał mi tylko życie piekielne, które wytrąciło mię z kolei, przygniatało ciężarem niepomiernym. On myślał tylko o zadowoleniu swych pożądań jako samiec (...) On tylko chciał ode mnie spełnienia obowiąków żony, na co powiedziałam mu, że jeżeli ulegnę jego prośbom, moge już należeć do pierwszego lepszego, że takie spełnianie obowiązków małżeńskich uważam za prostytucję. Na takich mękach przebyłam parę dni (...), a o ile jechałam wesoła i uśmiechnięta, wracałam jak po chorobie, blada, udręczona i przybita moralnie ${ }^{27}$.

Kreowanie siebie poprzez pisanie, „tworzenie” swojego obrazu (jako narracja o sobie) utożsamiane sa $z$ procesem konstruowania świadomości. Maja na to wpływ także czynności autorefleksji i autoanalizy, autooceny, których w przywoływanym pamiętniku jest wiele, pełniące funkcję porządkująca, terapeutyczną czy dyscyplinujaca. Prowadzenie własnych narracji czy narracji o sobie, podyktowane m.in. motywacjami twórczymi, stanowi równie waż-

\footnotetext{
${ }^{24}$ Ibidem.

25 Ibidem.

${ }^{26}$ P. Rodak, Dziennik pisarza: między codzienna praktyka piśmienna a literatura, „Pamiętnik Literacki” 2006, z. 4, s. 35.

27 Pamiętniki Marii Morzyckiej-Obuchowskiej..., s. 268.
} 
ne doświadczenie i życiowa próbę. Wskazuje na to przywoływany już Paweł Rodak, nazywając ów akt „zapisywaniem własnego pisania"28. Maria Morzycka nie do końca zrezygnowała $z$ własnych ambicji, nie do końca przyjęła rolę żony, matki i gospodyni. Nie wyznaczyła sobie w życiu funkcji sprzecznej $z$ jej wewnętrznym „ja”, nie uznała, że jest powołana tylko do tych zadań. Świadcza o tym dwie ważne decyzje: opuszczenie męża, odejście od niego na zawsze, oraz zostawienie dzieci. Postanowiła, że rozpocznie nowe, inne, wolne życie. Niezależna już pisała:

Po tylu latach okropnych, jak sen jaki złoty, przyszło ukojenie, jakieś błogie rozradowanie. Zdawało mi się, że nikt nigdy nie był ode mnie szczęśliwszy (...) Byłam szczęśliwa, że nareszcie jestem, że zachwycają się mna, że zwracają na mnie uwagę ${ }^{29}$.

Jednak i z nowym mężem, adwokatem Wrońskim, nie udało jej się do końca przeżyć pomyślnie i spokojnie, odpowiedzialnie i $z$ zachowaniem autonomii. Po kilku dobrych i udanych latach na nowo podjęła trud walki o siebie, swoje życie, prawa i powodzenie. Po śmierci córki Wroński właśnie ją oskarżył o to, że nie dopilnowała dziecka w chorobie, że niewystarczająco troszczyła się o mała, że zaniedbała swoje obowiązki matki, w ogóle nie biorąc pod uwage jej rozpaczy i cierpienia:

Marcin był prawie nieprzytomny, nie mówił nic, ale jak tylko mię zobaczył, pokazywał mi pięści. (...) Marcin szukał zapomnienia poza domem (...) W jego słowniku do mnie zjawiły się słowa pogardy i widocznej złości: „głupia, podła, nikczemna”, coraz częściej znajdowały się na jego ustach ${ }^{30}$.

Tymczasem Maria sama nosząc straszna boleść $w$ sercu, starała się nie pokazywać mężowi tego, co czuje i przeżywa, co $w$ głębi mej duszy dzieje się. Pisała tylko:

Pamiętam, że cały system nerwowy był porażony, jakieś okropne bóle nerwowe, spazmy zaczęły mię prześladować (...). Tylko ten, co

\footnotetext{
28 P. Rodak, op. cit., s. 35.

29 Pamiętniki Marii Morzyckiej-Obuchowskiej..., s. 273.

30 Ibidem, s. 341-342.
} 
doświadczył podobnych przejść, może zrozumieć rozpacz, boleść i to okropne, straszne, najprzykrzejsze uczucie niemocy, jaką człowiek czuje przed tym nieszczęściem, którego ani zmienić, ani odwrócić nie może, ogrom boleści w uczuciu, że nic pomóc nie może, że jest słaby, bezsilny wobec niezłomnych praw jakiejś mocy, która rządzi ziemią i kieruje według swojej woli ${ }^{31}$.

Małżonkowie się rozstali, Maria postanowiła się nie poddawać, rozesłałam listy do moich dzieci $z$ wiadomościa, że rozstajemy się $z$ Marcinem, bo on mię wypędza ${ }^{32}$. Trudno jej było zrozumieć postępowanie męża, nagle twardego, surowego, nieustępliwego i złośliwego, który rozsyłał listy z zapowiedzia, że mam [czyli Maria - B.W.D] suchoty, ze skargami na chora żonę. Dokuczał tym wszystkim, a nawet nie raczył podejść do mego łóżka, żeby sie przekonać, jak jest rzeczywiście. Siostra Marcina, znajac go, współczuła Marii w cierpieniu fizycznym i psychicznym, wiedziała, jaki jest okropny, sama bowiem doświadczyła wiele przykrości od niego, wiedziała, $\dot{z}$ e ani rodzonemu ojcu nie darował, ani rodzonej matce, wiedziała, $\dot{z} e$ jego mściwy charakter przed niczym się nie cofnie $i \dot{z} e$ przejednać go niczym nie można ${ }^{33}$. Ponowna rozłąka, a przy tym różne inne trudne, przykre, niekiedy tragiczne i smutne doświadczenia życiowe sprawiły, że mimo wielu dzieci i przyjaciół Maria pozostała kobieta samotna, ale samodzielna, bohaterska i do końca wierna swoim myślom i poglądom, jak na tamten czas nowoczesnym.

Maria Morzycka-Obuchowska była kobieta niezwykle silna, dzielna, postępową, rozumiejąca i wyrozumiałą (mimo wielu, może nieudanych, decyzji życiowych, jak chwilowe opuszczenie dzieci). Życie nie oszczędziło jej cierpień, zmartwień, bólu, wywołanych licznymi stratami, brakiem pieniędzy, przymusowym przesiedleniem, przeprowadzkami. Mimo wszystko potrafiła jednak zachować godność, samodzielność i nowoczesność w myśleniu i postępowaniu.

\footnotetext{
31 Ibidem, s. 341.

32 Ibidem, s. 348.

33 Ibidem, s. 373.
} 


\section{Bibliografia}

\section{Źródła}

Klijanienko-Pieńkowski Jerzy, Pan Pieńkowski? Da, oni żili zdieś... Wołyń, Syberia, Nałęczów, losy ziemiaństwa na podstawie dokumentów rodzinnych, Stalowa Wola: Wydawnictwo SZTAFETA, 2012, ISBN 978-83-63767-08-2.

\section{Opracowania}

Cieński Andrzej, $Z$ dziejów pamiętników w Polsce, Opole : Wydawnictwo Uniwersytetu Opolskiego, 2002, ISBN 8388796585.

Czapliński Władysław, Pamiętnikarstwo jako źródło dla historyka nowożytnego, „Pamiętnikarstwo Polskie” 1972, nr 2, s. 2-7, ISSN 03137-3234.

Czermińska Małgorzata, O autobiografii i autobiograficzności [w:] Autobiografia, red. Małgorzata Czermińska, Gdańsk : Słowo/Obraz/Terytoria, 2009, s. 5-17, ISBN 978-83-745-39326.

Czerska Tatiana, Między autobiografia a opowieścia rodzinna. Kobiece narracje osobiste $w$ Polsce po 1944 roku $w$ perspektywie historyczno-kulturowej, Szczecin : Wydawnictwo Uniwersytetu Szczecińskiego, 2011, ISBN 9788372418463.

Gautier Brigitte, Zaklęcia czarodziejki Vivien, czyli o autobiografii kobiecej [w:] Krytyka feministyczna. Siostra teorii i historii literatury, red. Grażyna Borkowska, Lilianna Sikorska, Warszawa : IBL, 2000, s. 152158, ISBN 838-745-6667.

Kraskowska Ewa, O tak zwanej „kobiecości” jako konwencji literackiej [w:] Krytyka feministyczna. Siostra teorii $i$ historii literatury, red. Grażyna Borkowska, Lilianna Sikorska, Warszawa : IBL, 2000, s. 200212, ISBN 838-745-6667.

Mrozik Agnieszka, Akuszerki transformacji. Kobiety, literatura i władza $w$ Polsce po 1989 roku, Warszawa : Stowarzyszenie Pro Cultura Litteraria, IBL, 2012, ISBN 978-83-61757-32-0.

Pekaniec Anna, Czy w tej autobiografii jest kobieta? Kobieca literatura dokumentu osobistego od początku XIX wieku do wybuchu II wojny światowej, Kraków : Księgarnia Akademicka, 2013, ISBN 9788376381817. 
Pekaniec Anna, Nie tylko dzienniki. Oryginalne warianty kobiecej literatury dokumentu osobistego (na wybranych przykładach), „Ruch Literacki" 2012, nr 4/5, s. 451-463, ISSN 0035-9602.

Perrot Michelle, Moja historia kobiet, tłum. Marta Szafrańska-Brandt, Warszawa : Instytut Wydawniczy PAX, 2009, ISBN 9788321118420.

Rodak Paweł, Dziennik pisarza: między codzienna praktyka piśmienna a literatura, „Pamiętnik Literacki” 2006, z. 4, s. 29-49, ISSN 00310514.

Sikorska-Kulesza Jolanta, Zło tolerowane. Prostytucja $w$ Królestwie Polskim w XIX wieku, Warszawa : Mada, 2004, ISBN 8389624133.

Walęciuk-Dejneka Beata, Kobieca koncepcja „bycia-w-świecie”: „ja” w rodzinie. Z „Pamiętników” Zofii Tołstojowej, „Prace Literaturoznawcze” 2015, nr 3, s. 197-208, ISSN 2353-5164.

Walęciuk-Dejneka Beata, Nowa „ja”. Autorskie stwarzanie siebie na podstawie „Pamiętników” Zofii Tołstojowej (wybór) [w:] Tożsamość kobiet: silne indywidualności $w$ sztuce, literaturze i religii, red. Joanna Posłuszna, Beata Walęciuk-Dejneka, Kraków : Aureus, 2014, s. 49-56, ISBN 978-83-60741-68-9.

Walęciuk-Dejneka Beata, „Oświecać lud, szerzyć kulturę, budzić zakrzepłe serca...". Faustyna Morzycka - samotna siłaczka [w:] Siła samotności. Zjawisko kobiecej samotności w kulturze i edukacji, red. Joanna Posłuszna, Kraków : Aureus, 2015, s. 65-74, ISBN 978-83-6074182-5.

Walęciuk-Dejneka Beata, W cieniu. Zofii Tołstojowej i Anny Dostojewskiej skrywane pisarstwo, „Studia z Historii Społeczno-Gospodarczej” [online], 2016, t. 16, s. 111-121, eISSN 2080-8313, ISSN 2450-6796.

Zimand Roman, „Zaproszenie” - pożegnanie [w:] Materiał dowodowy. Szkice drugie, Paryż : Instytut Literacki „PoMost”, 1992. 